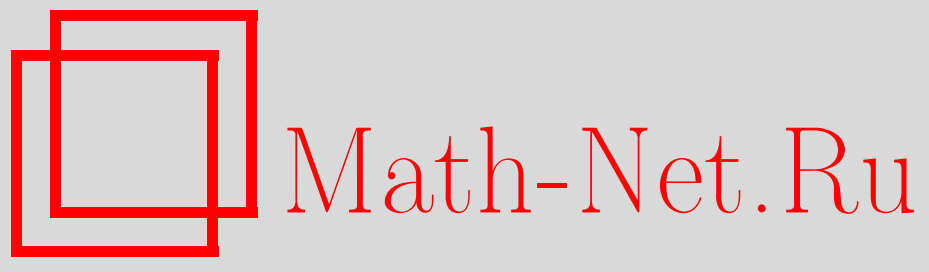

В. П. Маслов, Ностальгия по Д. В. Аносову, Матем. заметки, 2014, том 96, выпуск 3, 323-324

DOI: https://doi.org/10.4213/mzm10534

Использование Общероссийского математического портала Math-Net.Ru подразумевает, что вы прочитали и согласны с пользовательским соглашением http://www . mathnet.ru/rus/agreement

Параметры загрузки:

IP : 3.95 .254 .165

26 апреля 2023 г., 16:01:35

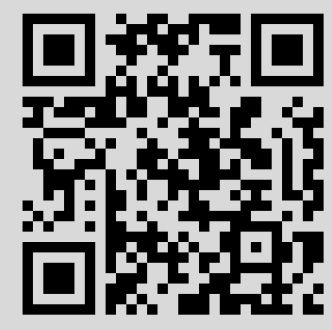




\section{Ностальгия по Д. В. Аносову}

\section{В. П. Маслов}

Академик Аносов был мне очень близким человеком. Перед его смертью я разговаривал с его самоотверженной женой Лидушей, а он крикнул из-за двери своей больничной палаты: "Пусть Маслов помнит о нашей дружбе".

У Аносова до нашей с ним встречи уже были три крупные работы, одна из которых, называемая ныне просто “Аносов" (подобно термину "рентген”), превратила его в классика. Эта работа отмечена рубрикой 37D20 в классификаторе Mathematical Subject Classification $2010^{1}$, что свидетельствует об открытии нового направления в математике. В наши дни идут ссылки уже не на эту работу, а на рубрику, которой соответствует инициированное Аносовым направление в математике.

Направление, которому соответствует большой поток работ, отбирается компьютером для включения в классификатор в виде рубрики. Фамилию ученого в название рубрики, правда, вносят эксперты. Но что еще можно зафиксировать в названии направления, если оно состоит из одной фамилии "Аносов"?

С Аносовым ушла часть меня самого, поэтому это частично поминки о самом себе или, как говорли раньше, панихида по самому себе. Дело в том, что в свое время у нас возникла команда, "мозговой центр" из математиков, разделивших математику на части. За одну из частей отвечал Аносов. Вернее, в ней царил Аносов.

Невозможно в деталях охватить всю науку. Достаточно знать, что есть эксперт по этой части, с которым мы настолько понимаем друг друга, что его мозг - это как бы часть моей памяти, которая включается, когда надо, и работает, как часть моего собственного мозга. Когда я читал свои собственные работы, то частично забывал и не улавливал логику доказательств. Тогда звонил к Аносову и мы вдвоем быстро разбирались.

К сожалению, с распадом СССР развалился и наш "центр." А то мы бы создали нового Бурбаки!

Общение в математической среде необходимо для развития науки. Мы скучаем от отсутствия собеседников и коллег одного с нами уровня. Аносов читал лекции своей жене за отсутствием близких ученых. Он умер из-за тоски по науке и научного одиночества. Он перестал принимать пищу. Ту пищу, мысли о которой поглощают в наше время математическую молодежь и отвлекают ее от чистой науки.

Научное взаимопонимание - это больше, чем простая дружба, это часть меня самого. И эта часть отмирала вместе с Аносовым.

Аносов был первым, кто стал пропогандировать за границей мою ротопринтную книжку "Теория возмущений и асимптотические методы," изданную в зеленом переплете в 1965 г. Он был председателем панели по обыкновенным дифференциальным уравнениям, выбирающей секционных докладчиков и выдвигающей пленарных докладчиков на международный математический конгресс, который собирался один раз в четыре года. Эта панель выдвинула меня сразу на пленарный доклад, но следующая инстанция предоставила мне секционный доклад по другой секции. (Приглашение на пленарный доклад я получил на следующем конгрессе). В этом отношении Аносов был моим крестным отцом.

Большинство математиков ценят решение "спортивных задач": когда проблема поставлена давно (например, теорема Ферма), над ней билось много ученых, а такой-то математик ее решил. Лично у меня, как у математика-практика, не вызывает интереса спортивное начало - перегнать таких-то знаменитостей! Например, та же теорема Ферма проверена на компьютере до таких больших чисел, что она ни у кого уже не вызывала сомнения.

\footnotetext{
${ }^{1}$ CM. http://www.ams.org

DOI: $10.4213 / \mathrm{mzm} 10534$
} 
Кому нужно строгое доказательсвто? Другое дело, открытия: новые методы, новые важные понятия. Например, открытие, содержащее формулировку самого Ферма. Или новые подходы, предложенные Г. Перельманом при решении проблемы Пуанкаре, с практической точки зрения, более существенны для развития науки, чем факт подтверждения знаменитой гипотизы. Хотя для личной славы, получения премий и т.п. это достижение победителя более убедительно.

Аносов, еще совсем молодой, рассказывал мне: "Вот я решил такую-то задачу, и со мной стали здороваться такие-то ученые, решил такую-то - стали здороваться такие-то." Назвал три проблемы. Я пошутил: "А я решил задачу в такой-то области, со мной перестали здороваться такие-то, решил такую-то, перестали здороваться такие-то." У него получалось "параллельно" и вызывало восхищение, а у меня "перпендикулярно" и вызывало удивление и недоверие.

Например, введение мной нуля в теорию чисел было столь непривычным, и так шокировало И.Р. Шафаревича, что он отметил это в интервью, посвященном всей его жизни. А его соавтор Илья Пятецкий-Шапиро абсолютно не поверил одной моей абстрактной теореме, приведенной в “зеленой” книге. Мы жили с ним в одной комнате на конференции в Новосибирске и поспорили по поводу этой теоремы. Он был человеком с мягким чувством юмора. Он предложил, чтобы проигравший наш спор во всеуслышание заявил: "Я сапог!" Он проиграл. По другой теореме мне проиграл Кириллов 40 бутылок вермута. Проспорил мне и сильнейший аналитик Г. Эскин. Это естественно, так как причиной спора в этих случаях были мои опубликованные теоремы.

А вот Аносов никогда не проспорил бы. Расскажу эпизод времен нашей молодости. Я опоздал на конференцию, которую организовал министр образования Узбекистана математик Сираджинов и которая проходила в горах. Я приехал на ишаке прямо на заседание, проходящее на открытом воздухе: кругом дорогие друзья Саша Кириллов, Митя Фукс и другие. (Где вы теперь? Далеко. Не скучаете там в США по родным нашим горам, ишакам? Да и нашим ли?) Я сразу включился в обсуждение какой-то старой проблемы из области Аносова и тут же предложил схему ее решения. Однако спортивной славы мне испытать не посчастливилось. В Москве Аносов указал мне на тончайшую ошибку в моем решении.

Ну что бы я делал без Аносова? И что я буду теперь делать без Аносова?

Прощай мой дорогой, Пьер Безухов, - спокойный и отзывчивый Дима Аносов! 